SIEGEL, FREDERIC R., and JOHANNES $H$. SCHROEDER, Department of Geology, The George Washington University, Washington, D.C., JOSE F. BONAPARTE, and RAFAEL HERBST, Fundación Miguel Lillo, Tucumán, Argentina

Clay Minerals in Selected Argentine Triassic UnITS

Three Upper Triassic (Rhaetian) formations which crop out in the Hoyada de Ischigualasto, San Juan Province, Argentina, have been analyzed partly for clay-mineral content. These continental units are conformable. From oldest to youngest, they are known as Estratos de los Rastros, Estratos de Ischigualasto, and Estratos de los Colorados. More than 80 samples representing observable changes in lithologic characteristics were taken at irregular intervals from 30 meters below to 30 meters above the two interformational boundaries. In the section studied, the boundary between the two lower formations is not well defined, either on lithologic or paleontologic characteristics, and that between the upper two formations is transitional in nature (through about 30 meters:.

The Estratos de los Colorados (redbeds with abundant gypsum) have illite as their principal, and in most cases only, clay mineral component. The two underlying formations contain an assemblage of kaolinite, montmorillonite, and illite. It is probable that the clay mineralogy reflects the environment in which it developed. The Estratos de los Colorados are thought to represent a desert environment in which alkaline conditions and the presence of potassium would be propitious for the formation of illite. The two underlying units, however, are dominantly composed of lacustrine deposits, commonly carbonaceous or bearing thin coal seams, and represent an environment different from that of the Estratos de los Colorados, i.e., a humid, reducing environment in which cations could be leached away and kaolinite would develop.

The clay mineralogy may be useful for locating more exactly the interformational boundary between the Estratos de los Colorados and the Estratos de Ischigualasto. However, there does not appear to be any significant difference in the clay mineralogy of the Estratos de Ischigualasto and the Estratos de los Rastros which would indicate the presence of an interformational boundary.

SIMONSON, RUSSELL R., Consulting Geologist, and GEORGE B. PICHEL, Union Oil Company of California, Los Angeles, Calif.

\section{Alaskan Exploration}

Oil seepages were noted in Alaska before the turn of the century. Exploration began as early as 1902 with the drilling of shallow wells near these seepages in the Cold Bay area of the Alaska Peninsula. In that same year drilling in the Yakataga area by the Chilkat Oil Company resulted in the discovery of the Katella field. This was Alaska's first oil field; however, it only produced 154,000 barrels from 1902 to 19.33 when the topping plant was destroyed by fire and the field abandoned.

Exploration was spasmodic until World War II. At that time the government spent 45 million dollars in exploration to develop oil in Naval Petroleum Reserve No. 4 on the Arctic North Slope. Seventy-five wells were drilled in the period 1945 1953. These wells resulted in the discovery of the Umiat oil field with reserves of approximately 70 million barrels. Several small gas fields also were found. These discoveries, though non-commercial in themselves, indicated to the industry that oil and gas could be found in the Arctic North Slope, one of the largest sedimentary basins in Alaska.

The real turning point in oil exploration in Alaska occurred in 1957 when the Richfield Oil Corporation discovered the Swanson River field. This field resulted from a seismic survey over a topographic high. Swanson River oil field has produced more than 60 million barrels of oil from 50 wells. and should recover more than 100 million additional barrels through pressure maintenance by gas injection which is presently underway.

The discovery of the Swanson River oil field began an extensive geophysical and exploratory effort on the Kenai Peninsula which still continues. By 1959 this effort had resulted in the discovery of the large Kenai gas field by Union Oil Company and Marathon, and several smaller gas fields. From 1959 until 1962 no other significant discoveries were made. It appeared that Swanson River oil field was a "freak" and that no additional oil would be found in the Cook Inlet. The industry, however, continued the search and was adventuresome enough to explore the cold waters of the Cook Inlet and to arquire leases there from the state of Alaska. Ir 1962 Pan American Petroleum, drilling one of these leases in the Cook Inlet, discovered the Middle Crourd Shoals oil field. This field, which has more than 1,500 feet of effective pay, indicated that oil fields could be found with sufficiently large reserves to justify the costly offshore operations in Alaska.

Industry effort since 196? has resulted in the discovery of several larte oil and gas fields, and has proved this to be one of the important oil-producing provinces of the ['nited States. In addition to the Middle Ground Shoils field. major oil accumulations have been found recently in the McArthur River, Trading Bay, West Fureland. North Redoubt, Granite Point, and Tyonek areas. Most of these discoveries are from thick pay section. In ardition to the Lower Kenai Hemlock conglomeratic sandstone, saturation has been found in multiple pity zones of the Middle Kenai Formation which hate better reservoir qualities than the Hemlock. All oil lields found in the Cook Inlet basin are undersaturated. Therefore, for maximum recovery, pressure maintenance will be required.

Reserves in excess of 1 hillion barrels of oil and 4 trillion cubic feet of was have been discovered in the Cook Inlet basin. The climatic, loxistic, and tide problems make the Cook Inlet misin one of the most expensive operating are in in fe world. Drilling costs are high because of the need tor expensive platforms designed to withstand the forc's of ice and tide plus the tremendous amount of ilrectional work, submarine pipelines, docks, terminials and other facilities neces-sary for the production if aule sil in a remote area. The industry, undaunted on the complexity and expense of the problems. continues to regatrd Alaska as an area with good prong protertial. Here the possibility still exists of finding hirce reserves in the United States.

The Cook Inlet bainin north of the Forelands has by now been explored relatively intensely, and the land is tightly leased. No company is interested in giving up any part of its acrease that is still unexplored. The industry as a whole. esperially those companies that were not fortunate enough :o acquire positions in the upper Cook Inlet, is hoking expectantly and hopeful. 
ly to the opening of the lower Cook Inlet by the Federal government for leasing, probably sometime in 1968. The areas of prime interest in Alaska today, and probably for the next few years, are lower Cook Inlet, Arctic North Slope, Bristol Bay, and Gulf of Alaska. It is interesting to note that 21 companies participated in a geophysical survey of Bristol Bay in 1966 and 20 companies participated in another survey in the Gulf of Alaska also in 1966. More and more, industry is finding that it behooves companies to join. where possible, to reduce the extremely high costs of operating in these areas. Alaska should continue for many years to be one of the important oil exploration areas in the United States.

SMITH, NEAL J., President, Society of Exploration Geophysicists, Houston, Tex.

Relationships Between Geologists and Geo PHYSICISTS

The treatment of this subject is best developed by one who has been on both sides and in the middle. The problem (briefly stated) is the general feeling that the two disciplines are not mutually appreciative of each other and are, therefore, less effective as an exploration team than would otherwise be the case.

One must understand that, as long as exploration continues to change, to foster the introduction of new methods, and to use men trained in a wide variety of specialties, complete mutual appreciation should not be expected. Complete appreciation will be possible only when the exploration industry is stagnant. It is management's business to optimize the situation by vigorous use and continuous training of earth scientists, and it is everybody's business to avoid unreasonable attitudes and statements.

SNYDER, JOHN L., American Geological Institute, Washington, D. C.

Educational Programs of American Geologitat. INSTITUTE

The American Geological Institute sponsors more than a dozen educational programs which are aimed at everyone from grade-school children to professional geologists. Among these are the Encyclopaedia Britannica Film project, a program which is developing an extensive set of films and film strips on aspects of geology and the other earth sciences; the Geology and Earth Science Sourcebook, designed as an aid to teachers on earth science; the Earth Science Curriculum Project for secondary school students, A.G.I.'s most extensive educational project; the Visiting Geological Scientist Program which has sent between 4.5 and 65 visitors to an average of 100 college departments every year since 1959; the International Field Institute which provides opportunities for college geology teachers to visit foreign areas of classic or unusual interest under the guidance of distinguished ge ologists; 3-day short courses held just before national meetings of the G.S.A. and designed to update professional geologists in some specific area of competence; and the Council on Education in the Geological Sciences whose purpose is to help improve geological education in American colleges and universities through publications, materials development, and by other means.

In addition to these major projects, A.G.I. publishes two career books-one for high school and one for college students; answers more than 3,000 letters a year on careers; provides a job-placement service for those seeking jobs of a temporary nature; and is put- ting out a basic bibliography of books, maps, and references essential for an undergraduate geology library.

STANLEY, DANIEL J., Smithsonian Institution, Washington, D. C., NOEL P. JAMES, Pan American Petroleum Corporation, Calgary, Alta., JAMES JUDD, Department of Geology, Rutgers University, New Brunswick, N.J., and JAMES I. MARLOWE, Bedford Institute of Oceanography, Dartmouth, Nova Scotia

Shelf to DeEp-Sea Shiment Transportation in

The Gulay Sibmartak Canyon Off Nova Scotia

Submarine calyons on the Atlantic continental margin off northeastern North America received large amounts of fluvial and fluvio-glacial sediment from emerged shelves during glacial stages. It has been stated that the supply of sediment to canyon heads, especially to those located far from coast lines, was virtually cut off after the Holocene sea-level rise, and that at the present time there is little sediment movement down these canyons. An examination of numerous piston core- collected in The Gully, the largest canyon on the highly dissected continental slope off Nova Scotia, Canada, indicates that the above generalizations do not apply in all canyons of this region.

The Gully heards on the vuter Scotian sbelf between Sable Island and Banquereau Banks, more than 100 nautical miles from the mainland. The Gully trends downslope southeastward in sinuous fashion for a distance of 35 miles to a depth of about 1.400 fathoms. The canyon is Vhaperl and the walls are steep with tradients of 1 an 2 . The ]ongitudinal gradient ranges from 1 on 9 to 1 on $\$ 9$ Small, precipitous tributary canyons enter the milin canyon, especially along the west wall.

Long cores collected at the base of the slope show an upward change in coloration from red (reworked till origin) to gray and olive (post-glacial). The number of coarse strata inrreases with depth, indicating that sediment rates decreased after the last rise in sealevel. However, the sediment sequence along the canyon length is proof of morlern active sedimentation Lenses of relatively clean sand in the upper reaches and near the steep walls of lateral tributary canyons are clearly derived from adjacent banks on the basis of minerology and faunal romposition. Normal bottom currents, slumps, and sand Hows probably moved these materials. In the sime treas, contorted lenses of silty and sandy day abound; localized slumping toward the canyon axis in the most important downslope transportation process lockets of sand and gravel, lyiner above nud in the canyon axis, and scour structures indicate that coarse clastics presently are being funneled downslope along the axis. Graded layers, 1-10 centimeters thick are uncovered within the canyon and correlation is not possible between adjacent cores. Turbidity currents presumably are active in moving some material is the deep sea but, in this area, are of lesser importare than either slumps or bottom currents.

STONE, RICHARD O., Department of Geology, University of Southern California, Los Angeles, Calif.

Unique Playa Sckapfr ind Forrow Near MCKTtTRICK, CaLIFOR NIA

An unusual occurrence of a well-defined playa scraper and furrow in a small playa-like area was observed near McKittrick, California. A 20-foot fill, made during construction of Culifornia Highway 30 , blocked a broad drainate hannel in the low hills 